This is an Accepted Manuscript of a chapter published in R. Mantie \& A. Ruthmann (Eds), Oxford Handbook of Technology and Music Education (pp. 257-276). Oxford University Press (2017). https://doi.org/10.1093/oxfordhb/9780199372133.013.25

\title{
Pedagogical Fundamentalism versus Radical Pedagogy in Music
}

\author{
Heidi Partti
}

The use of technologies in education has been under debate most likely since the first technological tool was ever introduced. Regardless of innovations in hardware and software, the debate on the question of whether the ongoing introduction of new technologies and media will add to or rob from the quality of education continues. Along with the interest, doubt, and excitement toward the use of modern technological instruments and interfaces in music teaching, the discussion revolving around music technology refers increasingly, often specifically, to the advent of digital media. Indeed, the possibilities for music-related interaction and participation enabled by digital technology, particularly in informal music learning environments, have recently gained mounting attention in the music education research literature (e.g., Salavuo, 2006; Waldron \& Veblen, 2008; Partti \& Karlsen, 2010; Väkevä, 2010; Miller, 2012; Partti \& Westerlund, 2012; Partti 2014; Michielse \& Partti, 2015). This chapter ${ }^{1}$ is based on an understanding that "the ongoing transition of our culture into a media culture" (Hepp, 2013, p. 1) has brought about far-reaching and thorough changes in our daily lives and institutions of education. As pointed out by Hepp (2013), the transition should not be underrated, as "the media — or, more exactly, communication via media- have increasingly left their mark on our everyday life, our identity and the way in which we live together" (p. 1). Thus, there is, or should be, a robust connection between explorations into musicians' developments, identities, values, and out-of school 'digital habitat"experiences (see Wenger, White, \& Smith, 2009) and the realities of the school. In this chapter, I make a case for the importance of systematic development of media literacy in music education. I will first explore the social-cultural changes that technological innovations, particularly the so-called new media technologies, have brought about in the wider culture of music making and learning. In the second section I will focus on the role of the school in the face of these social-cultural changes, and introduce two pedagogical strategies — namely, "pedagogical fundamentalism" and "pedagogical populism" - that institutions of formal music education have adopted to respond to these changes. In the 
subsequent two sections I will reflect on some of the limitations of the strategies regarding music education, especially in terms of the development of music-related expertise and capabilities for equal, responsible, and sustainable participation. Finally, I will argue for the importance of radical pedagogy in music education by suggesting that institutions of formal music education, the school in particular, should aim to build balanced approaches to new media that will equip and empower students to act as moral agents across a range of communities in physical and cyber spaces.

This chapter builds on a theoretical framework, provided particularly by writers in media studies (e.g., Buckingham, 2003, 2010; Jenkins, Clinton, Purushotma, Robison, \& Weigel, 2006; Davidson \& Goldberg, 2010) and critical pedagogy (e.g., Giroux, 1999, 2003, 2011; Freire, 1970/1996), as well as by social theories of learning (e.g., Wenger, 1998, 2006; Paavola \& Hakkarainen, 2005). Consequently, this chapter views music education as political education in which pedagogy is understood as a moral and political practice (e.g., Giroux, 1999, 2003, 2011) and learning is connected to students' growth as critical citizens with "the imperatives of social responsibility and political agency" (Giroux, 2003, p. 9). The development of such "radical pedagogy" (e.g., Suoranta, 2003; McGettigan, 2008) calls for an understanding of and commitment to the music teacher's role as a "critical companion" (Väkevä, 2013)supporting her students' growth into mature ways of thinking.

In addition to literature by other scholars, this chapter draws from my own research on music making and musical learning in the world of digital media. This chapter is motivated by an academic interest as a research scholar as well as by my personal experiences as a musician, music teacher, and music teacher educator. Rather than viewing myself as a "neutral" or "objective" observer on my mission to find and provide answers to questions or test theories, I consider myself a traveler engaged in a process of knowledge construction (see Kvale \& Brinkmann, 2009). Consequently, the observations of and understandings about the relationship between (digital) technologies and formal music education presented in this chapter are my interpretations, shaped by my own experiences and background.

\section{Mapping the Change: Learning Music in a Mediatizing World}

Technological breakthroughs have generally influenced social, cultural, educational, and political conditions. Researchers have identified various stages in the process of mediatization, that is, the development of increasing media influence in society. This development ranges from the stage in which people adopt the role of spectator coming into contact with the world via representations offered by the media to the stage in which we adapt ourselves "to the working routines of mass media and the conditions that the media set up" (Asp \& Esaiasson, 
1996, p. 80; see also Lundby, 2009; Couldry \& Hepp, 2013; Hepp, 2013). Currently, this adaptation to media logic is clearly seen in the ways people not only make media but also share it easily with others. This user generated content creation can take place both by conceiving new works from scratch and by playing along with commercially produced content.

Due to the novel ways that music audiences and musicians from different backgrounds can now join in archiving, producing, appropriating, and recirculating media content in (online) affinity groups, this emerging cultural phenomenon is often referred to as participatory culture (Jenkins et al., 2006; see also Partti \& Westerlund, 2012; Livingstone, 2013; Waldron, 2015). Although it has always been possible to learn music without entering into a music-learning institution, the opportunities for artistic expression, social participation, and musical learning, particularly those made accessible by the World Wide Web, are "unprecedented in both character and scale" (Gauntlett, 2011, p. 3). New media environments range from online composing projects (Partti \& Westerlund, 2013; Partti, 2014) to instrument or genre-specific virtual learning communities (Waldron \& Veblen 2008; Waldron, 2009) and to online remix contests (Jansen, 2011; Michielse, 2013; Michielse \& Partti, 2015), among many others.

With the arrival of new technologies, many of the old demarcations are being muddled. Te clearly set limits between different musical cultures, styles, and genres, formally educated experts and informally trained amateurs, playing and working, and consuming and producing are getting more indistinct day by day with every new technological invention. However, as liberating as the boundary blurring may well be in terms of participation and creativity, it does not come without practical, political, and ethical ramifications. For example, opportunities to protect young people from seeing and hearing potentially damaging or unsuitable media content, such as music videos including violent or explicitly sexual imagery, seem to be disappearing. And access to the cultural and social worlds in which children participate seems to be slipping away from the reach of adults (Buckingham, 2003, p. 32). This is not simply related to adults' technical (dis) abilities — a deficiency of technological capital, as it were. Adult access is frequently withheld, particularly due to our failure to comprehend the relevance and, indeed, the meaning of the content and practices that seem to have such a strong impact on young people. In other words, the blurring of boundaries in one place appears to have resulted in the redrawing of them in another. Thus, this blurring challenges formal education institutions to keep pace and to find their own role in the change and standpoint toward it.

\section{Choosing A Strategy for Facing the Change: Pedagogical Fundamentalism and Pedagogical Populism}

The rise of new and wider opportunities for learning music and communicating and exchanging musical ideas through simultaneous participation in various global and local 
communities through digital music and information technology also presents new questions regarding the role of the school and other institutions of formal music education. While explorations into the natural territories of people sometimes referred to as "digital natives" (e.g., Prensky, 2001, 2010) have advanced our understanding about the new ways, places, and spaces in which a growing number of (young) people can carry out music-related tasks, these explorations have not always been considered particularly helpful by practitioners working in schools and other institutions of formal music education. The globe may well be open for "new, even radically new, ways of conceiving, manipulating, mediating, consuming, and recycling music" (Väkevä, 2009, p. 9), but what does that have to do with the reality of the music teacher facing her students on a Monday morning at a local school?

In the field of music education, teachers, researchers, and policy-makers across the worldnot by any means limited to countries with advanced economies - are asking similar questions. Do children need to be saved from the corrupting influence of digital-technology-enabled mass media culture? Or are music teachers advised to stand back from the learning processes of their self-governing students? Are music teachers expected to protect their students from the ubiquitous influence of media or to zealously import models adopted from the ever-exciting virtual world, to jazz up the tediousness of the school classroom?

Next, I discuss two different pedagogical strategies that schools have adopted in the face of new, media-driven sociocultural changes. Following writings by the media education theorist David Buckingham $(2003,2010)$, I refer to these approaches as pedagogical fundamentalism and pedagogical populism.

\section{Pedagogical Fundamentalism: A Great Escape from the Perils of Media to the Safety of Traditions}

One strategy for addressing contemporary social change fueled by digital technologies has been to retreat from the risks and unpredictability of the mediatizing world to the (apparent) safety and clarity of the classroom's confines. Unlike constantly shifting new media environments, with their enormous amount of information, knowledge, and attitudes for which no one seems to be responsible, textbooks and clearly stated learning and assessment objectives - written by experts and published by verified institutes - may feel like welcome means of attaining stability. Consequently, schools have been accused of heading resolutely backward in the rhythm of a new educational fundamentalism.

Technology has irreversibly transformed the social and cultural experiences of students. At the same time, educational fundamentalism primarily views video games, tablets, and 
mobile phones as devices of distraction from instruction, and social networking sites as forums for the blossoming of narcissism and viciousness and the degradation of the quality of art and the diversity of knowledge (e.g., Keen, 2008; Aboujaoude, 2011; Koltay, 2011). For example, recently in music education, reservations about change have visibly been seen in regard to digital gaming. Rather than embracing the popularity of music video games and focusing on the benefits that gaming has been claimed to have in terms of deep learning, active participation, and acquaint ing oneself with various musical styles and skills (e.g., Gee, 2007; Missingham, 2007; Miller, 2012), many institutions of formal music education have exhibited caution and hesitancy in including music video games as part of classroom activities (Gower \& McDowall, 2012).

Pedagogical fundamentalism can also manifest itself in more subtle ways. An alternative to explicit resistance against technology-related changes is a reluctant acceptance of students' relationship with digital technology, but seasoned with the conviction of its corruptive influence and the importance of the teacher in enforcing cultural, moral, and political authority over the media that students experience. Whether due to the scorn of "the media's apparent lack of cultural value, as compared with the 'classics' of great art," or the fear over "the undesirable attitudes or forms of behaviour which they are seen to promote" (Buckingham, 2003, p. 6), students' relationships with new media technologies, according to pedagogical fundamentalism, are understood to represent a problem that needs to be solved through education.

\section{Pedagogical Populism: A Laissez-Faire Approach Based on Technological Determinism}

At the other extreme of possible strategies for responding to technology-driven changes is what Buckingham (2010) calls pedagogical populism. If pedagogical fundamentalism is based largely on denial, fear, and contempt, pedagogical populism draws on "a kind of populist cyber-libertarianism which claims that ordinary people will somehow be empowered by technology, and that digital media are inherently liberating and counter cultural" (p. 291). This approach is often justified by binary models of "old" versus "new," and posits that a more or less uniform generation now exists of "digital natives" who "think and process information fundamentally differently from their predecessors" (Prensky, 2001, p. 1) and should therefore be approached in completely new ways.

Based on "a form of technological determinism" (Buckingham, 2010, p. 292), according to which being exposed to technology will automatically result in social change and media literacy, pedagogical populism dismisses the need for teaching young people critical analysis, for instance. As Gauntlett (2007) states:"the patronizing belief that students should 
be taught how to 'read' the media is replaced by the recognition that media audiences in general are already extremely capable interpreters of media content ... thanks in large part to the large amount of coverage of this in popular media itself" (p. 3). As regards the music teacher, pedagogical populism results in a demand of continuous alertness. Unless teachers are fluent with downloading, editing, remixing, sharing, producing, deconstructing, reconstructing, and networking, they will "lose both the ability and even the right to teach" their students (Merrin, 2008). But even if the teacher would do her best to keep up with latest technological innovations, pedagogical populism ultimately leads to the question of the legitimacy of teaching. One wonders whether guidance in pedagogical situations is even necessary anymore. Buckingham (2010, p. 291) asks: “if ordinary people are already creating their own diverse meanings, participating and producing their own media, in [an] extremely capable and critical way ... then what do they need to learn, and what do we have to teach them?" With its focus on the importance of participation and creativity as goals in themselves and the significance of "the everyday meanings" (Gauntlett, 2007, p. 3 ) produced by people engaged in creative practices of media, pedagogical populism appears to suggest a haphazard music education where the teacher's role is to step back and leave students to their own devices, free from the patronizing eforts of helplessly dated "digital immigrants" (Prensky, 2001; 2010).

Although both pedagogical fundamentalism and pedagogical populism are common approaches in music education, the former is perhaps increasingly making room for the latter. However, and as I argue in the following section, neither strategy can be viewed as particularly helpful in terms of constructing educational practices that will support "the creation of a personal, life-long interest in any music" (Westerlund, 2008, p. 91) or guide students toward a stage of greater positive agency. Next, I will delve deeper into the implications that these approaches can be expected to have in music education, particularly in the school context.

\section{Pedagogical Fundamentalism and the Problem of Ignoring Mediatization}

\section{Cultures in School}

In the previous section I discussed a pedagogical strategy based on a defensive attitude toward social-cultural changes driven by new media technologies, referred to as pedagogical fundamentalism. To an extent, this strategy, and educators' cautiousness toward new technologies, is understandable and even justified. Contrary to what is sometimes assumed, technology does not make life simpler for teachers - quite the opposite. Few music teachers are trained to use technology in creative and versatile ways; even fewer are trained in media education. ${ }^{2}$ Introducing the latest gadgets in the classroom only for the sake of their novelty would hardly accelerate students' versatile learning. Furthermore, technological innovations 
undeniably entail phenomena with unattractive by-products related to, for instance, predatory capitalism (e.g., Suoranta, 2003; Schäfer, 2011) and individualism (e.g., Bakewell, 2011), as well as multiple legal issues of copyright and fair use (e.g., Demers, 2006; Dillon, 2006) that call for reflection and assessment.

However, as Buckingham (2003) reminds us, "if schools are to engage with children's media cultures, it is clearly vital that, in doing so, they do not simply attempt to reinscribe traditional notions of what counts as valid knowledge" (p. 33). Approaching new media through teacherly attempts at protection that undermine students' tastes and pleasures will hardly be taken seriously, and may, at worst, be counterproductive. Davidson and Goldberg (2010) express their concern regarding the widening gap "between the excitement generated by informal learning and the routinization of learning common to many of our institutions of formal education" (p. 49). One could ask whether music education operating from a place of stability, fear, and defensiveness is likely to help students to make connections, for instance, between the information and skills obtained in the music classroom and those encountered in online music communities.

In order to help students to understand how what they learn in school is related to their life outside the school, it is crucial, as already pointed out by Dewey (1900) well before the arrival of digital technologies, that the school engages with and even reflects social reality. Digital music culture is not merely about technological tools and innovations; it is about new understandings regarding, in particular, learning and the development of musicianship. Thus, explorations into this culture provide music educators with important information about broader changes related to the values and experiences of their students' out-of-school musical environments.

The digital-technology-enabled opportunities to participate in musical practices by copying, manipulating, reconstructing, playing with, and redistributing various musical materials instantaneously, and on an extremely large scale, have opened new perspectives to understanding the nature of musical learning. Rather than viewing learning solely as an individual cognitive process with a beginning and an end, acquired as the result of teaching and administered by the expert teacher in the music classroom context, musical learning can now be seen as part of any musical practice (e.g., Green, 2001; Salavuo, 2006; Partti \& Westerlund, 2012).

The view of musical learning as social participation draws on social theories of learning, with their emphasis on the significance of peers and communities for one's learning (Vygotsky, 1978; Lave \& Wenger, 1991; Wenger, 1998, 2006) and their focus on mediated 
activity between an individual and the environment in knowledge construction (Paavola, Lipponen, \& Hakkarainen, 2004; Paavola \& Hakkarainen, 2005). Although the understanding of learning as "essentially a social process" (Dewey, 1938/1998, p. 65) is not a result of the rise of digital technologies, new media environments provide an everincreasing number of possibilities for processes during which the participants in (online) learning communities construct their practices, meanings, and identities with respect to those communities (e.g., Salavuo, 2006; Partti \& Karlsen, 2010; Partti, 2013). Within this framework, learning can be compared to, for example, a trajectory (Wenger 1998, 2006; Barab, MaKinster, \& Scheckler, 2004), social construction (Riel \& Polin, 2004), and a social journey (Trayner, 2011).

If, once upon a time, there was a shared and well-established understanding about the development of music-related expertise as a linear process - guarded, initiated, and verified by the master teacher - that notion as the only option has by now been challenged by digital musicians' celebration of musical versatility, flexibility, and mobility in and between various musical communities (Partti, 2014). Instead of understanding the teacher as the only expert in the classroom, with the authority to steer the novice toward increasing challenges and expanding musicianship, the music-related participatory culture, with its strong emphasis on the values of musical breadth as well as cultural and creative fluidity, highlights the nature of musical expertise as a constant and dynamic process - one that is inherently social, openly shared by nature, and based on appropriation and collaboration (Partti \& Westerlund, 2012; see also Väkevä, 2010; Michielse \& Partti, 2015). A young pupil stepping into the music classroom is thus increasingly likely to arrive from a musical environment that represents not only new kinds of musical sites, including the latest technological devices and related knowhow, but also a new set of rules, understandings, and ideals about musicianship and the development of music related expertise.

With its tendency of designing music education solely according to particular cultural traditions and norms, educational fundamentalism fails to take into account the student's earlier and outside-school (informal) learning experiences, as well as the whole social environment through which learning takes place. As stated by Dewey (2008; see also Väkevä \& Westerlund, 2007; Westerlund, 2008), this kind of ignorance can have severe implications: "If we isolate the child's present inclinations, purposes, and experiences from the place they occupy and the part they have to perform in a developing experience, all stand upon the same level; all alike are equally good and equally bad. But in the movement of life different elements stand upon different planes of value" (Dewey, 2008, p. 280). One could ask whether neglecting or disapproving cultures of mediatization is likely to help the school to fulfill its role in supporting students to experience their global and local realities "as a holistic continuum" (Partti \& Karlsen, 2010, p. 377). Or will it, on the contrary, drive the wedge deeper into the dichotomy between 
music learning environments outside and inside school?

It follows logically from pedagogical fundamentalism that the music teacher's task is understood, to paraphrase Freire (1970/1996, p. 57), as being to regulate the way media "enters into" the students. As I have argued elsewhere, this dichotomy could, in turn, lead to a situation where "students will regard the values and practices of school-based music education as increasingly alien and meaningless" (Partti \& Karlsen, 2010, p. 377; see also Greenhow \& Robelia, 2009; Davidson \& Goldberg, 2010). Therefore, with its tendency to disregard the school's role in helping to "bridge the widening gap between the school and the world of children's out-of-school experience" (Buckingham, 2003, p. 32), pedagogical fundamentalism offers too narrow an approach to issues related to the music-related mediatizing world.

\section{Pedagogical Populism and the Issue of Music Education's Legitimacy of Teaching}

If the school is required to be involved in and reflect social reality, as suggested above, one could ask whether formal music education should aim for a new kind of pedagogy altogether. The pedagogical populism strategy questions not only the competence of digital immigrants to teach digital natives but the validity of what is taught.

The issue of the legitimacy of teaching is not a new one in music education, as it has been preceded by similar discussions in popular music pedagogy (see Green, 2001, 2008; Folkestad, 2006; Allsup, 2008; Väkevä, 2009, 2013; Karlsen \& Väkevä, 2012). Over the last decade, in the search for alternatives for traditional classroom teaching, an increasing number of investigations have been made into popular musicians' informal learning strategies. For some, understanding the importance of "garage rock band" practices has meant choosing a pedagogy in which the teacher's role is hardly more than that of a bystander observing students making their own decisions. Leaving the teacher on the sidelines of classroom practices has been justified by, for instance, the importance of providing students with learning experiences that are more authentic and meaningful to them.

According to this line of thinking - not unlike that in new-media-related pedagogical populism-young people develop, seemingly all by themselves, an ability to critically analyze music and performance quality, as well as global music industry manipulative practices, by learning music that they like (see Green, 2008). Such "informal pedagogy" is criticized by those who argue that the recognition of "the multi-faced and mutable ontological status for musical reality" should not result in leaving the student alone (Väkevä, 2009, p. 24; see also Allsup, 2008) but rather in facilitating a pedagogical environment in which the student's reality contributes to the educational purpose and direction (e.g., Väkevä 
\& Westerlund, 2007; Westerlund, 2008; Väkevä, 2013).

While digital technologies have brought about great opportunities for artistic expression, sharing, and participation for many, they have hardly liquidated social inequality once and for all. There are still prominent social differences in access levels to new media and "the opportunities for participation they represent," both between and within societies (Jenkins et al., 2006, p. 12, see also Greenhow \& Robelia, 2009; Santos, Azevado, \& Pedro, 2013). Many young people seem to acknowledge the potential of the technology provided for sophisticated content creation and sharing but lack the social or personal motivation to actually generate original cultural content, even in countries with wide access to multimedia abilities and broadband. "To a large extent, the most active participants in the creative world of Web 2.0 are the "usual suspects'" (Buckingham, 2010, p. 294) - those with enough social and cultural capital to participate and contribute in the society and culture already. Te laissez-faire approach of pedagogical populism therefore appears to be based on rather naïve assumptions about inclusiveness and "the transformation of former audiences into active participants and agents of cultural production” (Schäfer, 2011, p. 10).

As a public institution, the school has the opportunity to provide young people with "social, intellectual and cultural experiences that they might not otherwise have" (Buckingham, 2010, p. 297). This, in turn, may well be one of the most important ways to prevent the emergence of "an educational 'underclass' that is effectively excluded from access, not merely to economic capital but to social and cultural capital as well" (Buckingham, 2003, p. 203) especially as digital access often seems to correlate "with educational opportunity and wealth" (Davidson \& Goldberg, 2010, p. 51). In the context of the still-existent "participation gap" of digital music culture, the importance of the school is thus highlighted, rather than diminished, in regard to equipping pupils with the requisite social-cultural competencies, skills, and knowledge to overcome digital divides.

As suggested above, the issue of access to media environments does not refer only to specific skill sets related to effectively using digital devices and information networks. Increasingly often, navigating rapidly changing digital habitats requires social skills that enable one to interact within larger communities. Although digital technologies have enabled new possibilities for creative activities and interactions that reach beyond geographical, cultural, and various other borders, merely bringing people together and exposing them to diversity will hardly generate tolerance and respect. In fact, as can be witnessed in the mounting hate speech in online communities, for example, encounters with varying perspectives tend to result in conflicting and competing values, norms, assumptions, and "claims about the meanings of shared artifacts and experiences" (Jenkins et al., 2006, p. 52). Instead of inspiring people to 
take action in response to suspicious and fearful stereotyping, facing diversity appears to frequently breed withdrawing from those who are different (Putnam, 2007; Sennett, 2012).

New media environments provide multiple opportunities to encounter different views and ways of life, but often in the form of anonymous opinions, comments, and appraisals. Learning to ethically and responsibly communicate, share, collaborate, and socialize in the world of "anonymous diversity" - the world where it may not be necessary, or even possible, to directly face the consequences of one's words and attitudes - calls for emotional maturity and critical and social agency (e.g., Dijck, 2009; Dijck \& Nieborg, 2009).

The question arises whether or not the "hands-of" approach to teaching can successfully provide young people with opportunities for active reflection on their media experiences that would further help them to "master the skills they need as citizens and consumers" (Jenkins et al., 2006, p. 16). Will the music classroom based on the principles of pedagogical populism support students enough in developing "the ethical norms needed to cope with a complex and diverse social environment online" (p. 12; see also Schäfer, 2011)?

Buckingham and colleagues have shown (Buckingham, Grahame, \& Sefon-Green, 1995) that the laissez-faire strategy according to which the teacher should deliberately refrain from direct instruction is likely to implicitly endorse values and divisions of labor that further, rather than prevent, the (re)production of stereotypes, discrimination, and inequalities. In addition, Greenhow and Robelia (2009) in their study on informal learning and identity formation in online social networks noticed that high school students participating in online communities demonstrated extremely limited understandings of the ethical and legal issues involved in their participation in semi-public online spaces. According to the researchers, the young peoples' disregard for social and ethical responsibility mirrored "the lack of understanding on the part of educators who are supposed to model digital citizenship behaviors" (p. 135; see also Greenhow, Walker, Donnelly, \& Cohen, 2007).

In other words, although the widening opportunities for participation in digital technologyenabled creative practices have provided important means for learning, participation and creativity are only one side of the coin. They should not be treated as end goals in themselves. Participation may or may not be democratic, empowering, countercultural, or liberating, and the experience of creative production is highly unlikely to automatically result in critical literacy (Buckingham, 2010; see also Luke, 2000). As such, it is important that one be able to "step back from immediate experience, in order to reflect and to analyze" (Buckingham, 2010, p. 299), to evaluate, and to discuss those experiences with others, thus gaining a deeper understanding of different media dimensions. It seems 
that pedagogical populism collapses from educational naivety; this naivety lacks the practical depth and breadth to prepare students for interacting with new media and approaching global music-making and learning environments on equal terms.

I have argued that it is just as unhelpful to adopt the strategy of pedagogical fundamentalism, according to which students are passive victims of harmful and damaging media, as that of pedagogical populism, which uncritically buys into utopian fantasies about social change autonomously produced by technology. Instead, I will suggest an approach that emphasizes media education in music education as a form of preparation. As stated by Buckingham (2003), this paradigm seeks to develop students' understanding of, and participation in, the media culture that surrounds them by highlighting "the importance of media education as part of a more general form of 'democratic citizenship' " (p. 13) while at the same time recognizing the significance of the enjoyment and pleasure people experience with media.

To conclude, I will discuss the relationship between formal music education and new media, particularly from the viewpoint of digital citizenship competency development. I will argue that the school, as a public institution, has a unique opportunity-indeed, the responsibility - to address "the unequal access to the opportunities, experiences, skills and knowledge that will prepare youth for full participation in the world of tomorrow" (Jenkins et al., 2006, p. 3). I will also envision the music classroom as a place of dialogue and reflection, contributing to the development of the media literacy and cultural competencies required for full involvement in the music-related mediatizing world.

\section{Toward Radical Pedagogy in Music Education}

As stated throughout this chapter, the phenomena currently emerging from a rapidly changing digital music culture are relevant also to the music classroom, as they inform the educator about new ways people are engaged in music and participate in music related practices. However, these phenomena do not diminish the teacher's responsibility for organizing music learning and teaching contexts. In an age of digital technologies, the teacher has an even more importance, in recognizing musical growth opportunities and being a "critical companion" during the growth process (Väkevä, 2013, p. 102). The school classroom as "a little community," as envisioned by Dewey (1976, p. 20), should therefore be a place where students' musical creativity and aspirations are taken seriously, and where there is enough space for cooperative engagement between the students and teacher. Rather than adding a media literacy course to the music education curriculum, this continuous dialogue would enable different modes of learning, as well as critical discussions about 
values, ideas, norms, and subtle forms of propaganda behind various local and global environments and activities of music making. To paraphrase Dewey, such music education would provide fertile ground for the growth not only of the students' ability to "act with and for others" (2008, p. 98) but also of their capacity to independently consider the ways, places, and spaces of music-related activities and their possible moral consequences.

This kind of an approach to the relationship between the school and technology focuses beyond technology and media as teaching materials and curriculum content. Despite the importance of questions related to tools, technical skills, and teaching methods, we should ask more questions about how we teach, and what is not taught in school. Is the school dismissing or making the most of its chance for a radical — that is, far-reaching and profound - examination of the world? Are we considering "as broadly as possible the nature of education as it exists today - as well as how it might change as we move into the future" (McGettigan, 2008)? ${ }^{3}$ While the world keeps on changing through the impact of technological innovations and globalization, are we, as educators, aiming to create "the formative culture of beliefs, practices, and social relations that enable individuals to wield power, learn how to govern, and nurture a democratic society that takes equality, justice, shared values, and freedom seriously" (Giroux, 2011)? Echoing the voice of Dewey, Giroux states that this kind of formative culture arises from developing pedagogical practices that facilitate "conditions for producing citizens who are critical, self-reflective, knowledgeable, and willing to make moral judgments and act in a socially responsible way" (2011).

Digital citizenship, a notion referring to "an informed and participatory citizenry whose online behaviors simultaneously uphold standards for legal, ethical, safe, responsible, and respectful uses of technology" (Greenhow \& Robelia, 2009, pp. 125-126), is advocated also by UNESCO, within its "media literacy" curriculum (Wilson et al., 2011), along with national curricula across the world. Indeed, these institutions support the development of digital citizenship competencies. Helping students to bridge the gap between the knowledge, skills, experiences, and ideals acquired through interacting with new media and those encountered in the music classroom calls for the recognition of the knowledge that students already possess and the significant roles that digital technologies play in their lives. Hence, the school should neither be reduced to a mere irrelevance nor viewed as "a training ground for the new 'digital economy' " (Buckingham, 2010, p. 297). Instead, as suggested in this chapter, the school can become a seedbed for the growth of educated hope-hope understood as "a pedagogical and performative practice that provides the foundation for enabling human beings to learn about their potential as moral and civic agents" (Giroux, 2012). Music education in the mediatizing world thus becomes a collaborative inquiry within which the teacher can let go of the requirement of having all the answers. The teacher 
can now face the questions related to the mediatizing world as one who, along with her students, also asks questions, speculates, ponders, and wonders. As reminded by Suoranta (2003, p. 204), the teacher can feel at ease about experimenting with new things, and about expanding her field of teaching by allowing media culture meanings to futter into the classroom with her students.

\section{Epilogue: A Four-Track Recorder and Educated Hope}

During a recent visit to get acquainted with the music education system of a post-conflict society in Asia, I had the privilege to observe one of the most inspiring music classes I have witnessed in a long time. The music teacher, an elderly gentleman, introduced us to the technological equipment available in his music class, consisting of a hand pumped organ, a four-track recorder, and a cassette player. In the context of a country where music teaching was not normally part of the school instruction, the tools marked a significant achievement. During the subsequent 45 minutes, the young pupils performed songs for us composed by the teacher, who, with the help of his four-track recorder, had created backing tracks to accompany the enthusiastic, sparkly-eyed singing. I could feel 30 pairs of passionate eyes (including those of the teacher) on us the moment the teacher pressed "play" on his cassette player. We were equally impressed by the pupils' joyful excitement and the teacher's proficient use of what to us represented a rudimentary form of technology. I could not help wondering whether this was exactly what technology in music education looks like at its best: the teacher who utilizes the technology at hand, be it the most recent model of tablet or a secondhand track recorder, in order to manifest educated hope by caring for his pupils enough to invest all his humanity, compassion, creativity, pedagogical love, and people skills into helping them to grow into maturity and agency.

In the advent of digital technology and media cultures, Freire's (1970/1996) words about education as the practice of freedom are timelier than ever: "Education as the practice of freedom ... denies that man is abstract, isolated, independent, and unattached to the world; it also denies that the world exists as a reality apart from people. Authentic reflection considers neither abstract man nor the world without people, but people in their relations with the world" (p. 62). Digital technology and media are not phenomena out there. In our swiftly mediatizing world, the music teacher, along with her students, is an indigenous species in digital habitats. Therefore, rather than observing the world of media from afar, the teacher is called on an explorative journey to gain understanding about a cultural phenomenon with which she is personally intertwined. The role of the music teacher as a critical companion within cultures “"moulded' by the media" (Hepp, 2013, p. 2) is neither to impose her own views and meanings on her students' experiences nor to abandon children to approach global environments alone. 
Now more than ever it is time to make the classroom a place of dialogue and critical discourse, through which the students along with the teacher are constantly engaging in the world by conceiving and evaluating ideas and their moral consequences (see Dewey, 1980; Hansen, 2007). Regardless of how worthwhile investigations into new media and informal learning contexts are, it is crucial to open up formal spaces for critical discussions and active reflection (see Allsup, 2008). It is difficult to imagine any other place more suitable for engaging in such dialogue than the school classroom, which daily assembles the members of a whole generation from every possible background under its roof.

\section{Notes}

1. This research has been undertaken as part of the ArtsEqual project funded by the Academy of Finland's Strategic Research Council from its Equality in Society programme (project no. 293199).

2. For example, the results from a recent study on Finnish school music teachers' use of technology in their classroom activities suggest that, according to the teachers' own estimation, one of the key challenges preventing them from adopting digital technologies more actively and widely in their teaching is that they lack the skills to do so, not having learnt them during teacher training (Partti, 2015).

3. Importantly, this holistic approach to the development of media literacy in music education, woven through the entire educational system, highlights the significance of establishing teacher education that prepares teachers to analyze and understand different viewpoints and policy languages. Rather than preparing future teachers to merely become fluent in their subject content, music teacher education should also, and in particular, provide for the development of competences and an outlook that enables teachers to cope with cultural pluralism in increasingly challenging and volatile settings (e.g., DarlingHammond, 2005).

\section{References}

Aboujaoude, E. (2011). Virtually you: The dangerous powers of the e-personality. New York: Norton.

Allsup, R. E. (2008). Creating an educational framework for popular music in public schools:Anticipating the second-wave. Visions of Research in Music Education, 12, 1-12.

Asp, K., \& Esaiasson, P. (1996). The modernization of Swedish campaigns: Individualization, professionalization, and medialization. In D. L. Swanson, \& P. 
Manicini (Eds.), Politics, media, and modern democracy: An international study of innovations in electoral campaigning and their consequences (pp. 73-90). Westport, CT: Greenwood.

Bakewell, S. (2011). How to live: A life of Montaigne in one question and twenty attempts at an answer. London: Vintage.

Barab, S. A., MaKinster, J. G., \& Scheckler, R. (2004). Designing system dualities: Characterising an online professional development community. In S. A. Barab, R. Kling, \& J. H. Gray (Eds.), Designing for virtual communities in the service of learning (pp. 53-90). NewYork:Cambridge University Press.

Buckingham, D. (2003). Media education: Literacy, learning and contemporary culture. Cambridge, UK: Polity Press.

Buckingham, D. (2010). Do we really need media education 2.0? Teaching in the age of participatory media. In K. Drotner \& K. C. Schrøder (Eds.), Digital content creation: Perceptions, practices and perspectives (pp. 287-304). NewYork: Peter Lang.

Buckingham, D., Grahame, J., \& Sefon-Green, J. (1995). Making media: Practical production in media education. London: English and Media Centre.

Collins, A., \& Halverson, R. (2009). Rethinking education in the age of technology. The digital revolution and schooling in America. NewYork: Teachers College, Columbia University.

Couldry, N., \& Hepp, A. (Eds.). (2013, August). Conceptualizing mediatization [Special issue]. Communication Theory.

Darling-Hammond, L. (2005). Teaching as a profession: Lessons in teacher preparation and professional development. Phi Delta Kappan, 87(3), 237-240.

Davidson, C. N., \& Goldberg, D. T. (2010). The future of thinking: Learning institutions in a digital age. Cambridge, MA: MIT Press.

Demers, J. (2006). Steal this music: How intellectual property law affects musical creativity. Athens: University of Georgia Press. 
Dewey, J. (1900). The school and society. Chicago: University of Chicago Press.

Dewey, J. (1998). Experience and education (60th anniversary ed.). Indianapolis: Kappa

Delta Pi. (Original work published 1938)

Dewey, J. (1976). The Middle Works, 1899-1924: Vol. 1. 1899-1901 (J. A. Boydston, Ed.). Carbondale: Southern Illinois University Press.

Dewey, J. (2008). The Middle Works, 1899-1924: Vol. 2. 1902-1903 (J. A. Boydston,

Ed.). Carbondale: Southern Illinois University Press.

Dewey, J. (1980). The Middle Works, 1899-1924: Vol. 9. 1916 (J. A. Boydston, Ed.).

Carbondale: Southern Illinois University Press.

Dewey, J. (2008). The Later Works, 1925-1953: Vol. 6. 1931-1932 (J. A. Boydston, Ed.).

Carbondale: Southern Illinois University Press.

Dijck, J. van. (2009). Users like you? Theorizing agency in user-generated content. Media Culture Society, 31(1), 41-58.

Dijck, J. van, \& Nieborg, D. (2009). Wikinomics and its discontents: A critical analysis of Web 2.0 business manifestos. New Media \& Society, 11(4), 885-874.

Dillon, T. (2006). Hail to the thief: Appropriation of music in the digital age. In K. O’Hara \& B. Brown (Eds.), Consuming music together: Social and collaborative aspects of music consumption technologies (pp. 289-306). Dordrecht: Springer.

Folkestad, G. (2006). Formal and informal learning situations or practices vs. formal and informal ways of learning. British Journal of Music Education, 23(2), 135-145.

Freire, P. (1996). Pedagogy of the oppressed. London: Penguin Books. (Original work published 1970).

Gauntlett, D. (2007). Wide angle: Is it time for media studies 2.0? Media Education Association Newsletter, 5, 3-5.

Gauntlett, D. (2011). Making is connecting: The social meaning of creativity, from DIY and knit ting to YouTube and Web 2.0. Cambridge, UK: Polity Press.

Gee, J. P. (2007). Good video games and good learning: Collected essays on video games, 
learning and literacy. NewYork: Peter Lang.

Giroux, H. (1999). Performing cultural studies as a pedagogical practice. In D. Slayden \& R. K. Whillock (Eds.), Soundbite culture: The death of discourse in a wired world (pp. 191202). Thousand Oaks, CA: Sage.

Giroux, H. (2003). Public pedagogy and the politics of resistance: Notes on a critical theory of educational struggle. Educational Philosophy and Theory, 35(1), 5-16.

Giroux, H. (2011). On critical pedagogy (Kindle version). NewYork: Continuum.

Giroux, H. (2012). The Occupy movement and the politics of educated hope. Retrieved from http:// truth-out.org/news/item/9237-the-occupy-movement-and-the-politics-of-educatedhope.

Gower, L., \& McDowall, J. (2012). Interactive music video games and children's musical development. British Journal of Music Education, 29(1), 91-105.

Green, L. (2001). How popular musicians learn: A way ahead for music education. Hampshire, UK:Ashgate.

Green, L. (2008). Music, informal learning and the school: A new classroom pedagogy. Hampshire, UK: Ashgate.

Greenhow, C., \& Robelia, B. (2009). Informal learning and identity formation in online social networks. Learning, Media and Technology, 34(2), 119-140.

Greenhow, C., Walker, J., Donnelly, D., \& Cohen, B. (2007). Fair use education for the twenty first century: A comparative study of students' use of an interactive tool to guide decision making. Innovate, 4(2).

Hansen, D. (2007). Ideas, action, and ethical vision in education. In D. Hansen (Ed.), Ethical visions of education: Philosophies in practice (pp. 1-18). NewYork: Teachers College Press.

Hepp, A. (2013). Cultures of mediatization. Cambridge, UK: Polity Press. Jansen, B. (2011), Where credit is due: Cultural practices of recorded music. Unpublished doctoral dissertation, Amsterdam University. 
Jenkins, H., Clinton, K., Purushotma, R., Robinson, A. J., \& Weigel, M. (2006). Confronting the challenges of participatory culture: Media education for the 21st century. Retrieved from http://www.digitallearning.macfound.org/atf/cf/\%7B7E45C7E0-A3E0-4B89-AC9C E807E1B0AE4E\%7D/JENKINS_WHITE_PAPER.PDF.

Karlsen, S., \& Väkevä, L. (Eds.). (2012). Future prospects for music education: Corroborating informal learning pedagogy. Newcastle upon Tyne, UK: Cambridge Scholars.

Keen, A. (2008). The cult of the amateur: How blogs, MySpace, YouTube, and the rest of today's usergenerated media are destroying our economy, our culture, and our values (Rev. ed.) NewYork: Doubleday.

Koltay, T. (2011). New media and literacies: Amateurs vs. professionals. First Monday, 16, 1-3. Retrieved from http://frstmonday.org/htbin/cgiwrap/bin/ojs/index.php/fm/article/view/ 3206/2748.

Kupiainen, R., Sintonen, S., \& Suoranta, J. (2008). Decades of Finnish media education. Finnish Society on Media Education. Retrieved from http://www.mediakasvatus.f/publications/ decadesofnnishmediaeducation.pdf.

Kvale, S., \& Brinkmann, S. (2009). InterViews: Learning the craft of qualitative research interviewing. Thousand Oaks, CA: Sage.

Lave, J., \& Wenger, E. (1991). Situated learning: Legitimate peripheral participation. Cambridge, UK: Cambridge University Press.

Livingstone, S. (2013). The participation paradigm in audience research. Communication Review, 16(12), 21-30.

Luke, C. (2000). Cyber-schooling and technological change: Multiliteracies for new times. In B. Cope \& M. Kalantzis (Eds.), Multiliteracies: Literacy learning and the design of social futures (pp. 69-91). London: Routledge.

Lundby, K. (Ed.). (2009) Mediatization: Concept, changes, consequences. NewYork: Peter Lang. McGettigan, T. (2008, April 8). What is radical pedagogy? Retrieved from http://ezrawinton. com/2008/04/08/what-is-radical-pedagogy/.

Merrin, W. (2008). Media studies 2.0. Retrieved from http://twopointzeroforum.blogspot.com/. 
Michielse, M. (2013). Musical chameleons: Fluency and flexibility in online remix contests. $M / C$ Journal, 16(4).

Michielse, M., \& Partti, H. (2015). Producing a meaningful difference: The significance of small creative acts in composing within online participatory remix practices. International Journal of Community Music, 8(1), 27-40.

Miller, K. (2012). Playing along: Digital games, YouTube, and virtual performance. Oxford: Oxford University Press.

Missingham, A. (2007). Why console-games are bigger than rock ' $n$ ' roll: What the music sector needs to know and how it can get a piece of the action. Retrieved from http://www.youthmu sic.org.uk/assets/fles/Console\%20games\%20and\%20music_1207.pdf.

Paavola, S., \& Hakkarainen, K. (2005). The knowledge creation metaphor — an emergent epistemological approach to learning. Science \& Education, 14, 535-557.

Paavola, S., Lipponen, L., \& Hakkarainen, K. (2004). Models of innovative knowledge communities and three metaphors of learning. Review of Educational Research, 74(4), 557-576.

Partti, H. (2013). Oopperasäveltäjäksi oppimassa: Opera by You—verkkoyhteisö musiikillisen asiantuntijuuden kasvualustana [Learning to be an opera composer: The Opera by You online community as a platform for the growth of music-related expertise]. Musiikki, 1, 33-50.

Partti, H. (2014a). Cosmopolitan musicianship under construction: Digital musicians illuminating emerging values in music education. International Journal of Music Education, 32(1), 3-18.

Partti, H. (2014b). Supporting collaboration in changing cultural landscapes: Operabyyou.com as an arena for creativity in "kaleidoscope music." In M. S. Barrett (Ed.), Collaborative creative thought and practice in music (pp. 207-220). Surrey, UK:Ashgate.

Partti, H. (2015, May 3-5). The bliss and dread of creative music making: Finnish music teachers' approaches to teaching composing. Presentation at the Nordic Network for Research in Music Education Conference, Helsinki.

Partti, H., \& Karlsen, S. (2010). Reconceptualising musical learning: New media, identity and community in music education. Music Education Research, 12(4), 369-382. 
Partti, H., \& Westerlund, H. (2012). Democratic musical learning: How the participatory revolution in new media challenges the culture of music education. In A. R. Brown (Ed.), Sound musicianship: Understanding the craft of music (pp. 300-312). Newcastle Upon Tyne, UK: Cambridge Scholars.

Partti, H., \& Westerlund, H. (2013). Envisioning collaborative composing in music education: Learning and negotiation of meaning in operabyyou.com. British Journal of Music Education, 30(2), 207-222.

Prensky, M. (2001). Digital natives, digital immigrants. On the Horizon, 9(5), 1-6.

Prensky, M. (2010). Teaching digital natives: Partnering for real learning. Thousand Oaks, CA: Sage.

Putnam, R. D. (2007). E pluribus unum: Diversity and community in the twenty-first century (2006 Johan Skytte Prize Lecture). Scandinavian Political Studies, 30(2), 137-174.

Riel, M., \& Polin, L. (2004). Online learning communities: Common ground and critical differences in designing technical environments. In S. A. Barab, R. Kling, \& J. H. Gray (Eds.), Designing for virtual communities in the service of learning (pp. 16-50). NewYork:Cambridge University Press.

Salavuo, M. (2006). Open and informal online communities as forms of collaborative musical activities and learning. British Journal of Music Education, 23(3), 253-271.

Santos, R., Azevedo, J., \& Pedro, L. (2013). Digital divide in higher education students' digital literacy. In S. Kurbanoğlu, E. Grassian, D. Mizrachi, R. Catts, \& S. Špiranec (Eds.), Worldwide commonalities and challenges in information literacy research and practice (pp. 178-183). NewYork: Springer.

Schäfer, M. T. (2011). Bastard culture! How user participation transforms cultural production. Amsterdam:Amsterdam University Press.

Seel, J. (2001). Plugged in, spaced out, and turned on: Electronic entertainment and moral minefields. Journal of Education, 179(3), 17-32.

Sennett, R. (2012). Together: The rituals, pleasures and politics of cooperation (Kindle 
version). London: Penguin Books.

Suoranta, J. (2003). Kasvatus mediakulttuurissa [Education in media culture]. Tampere, Finland: Vastapaino.

Trayner, B. (2011, April 17). Social learning—on a high horse. Retrieved from http://www.bev trayner.com/base/.

Väkevä, L. (2009). The world well lost, found: Reality and authenticity in Green's “New Classroom Pedagogy." Action, Criticism, and Theory for Music Education, 8(2), 7-34.

Väkevä, L. (2010). Garage band or GarageBand®? Remixing musical futures. British Journal of Music Education, 27(1), 59-70.

Väkevä, L. (2013). Informaali oppiminen, musiikin opetus ja populaarimusiikin pedagogiikka [Informal learning, music teaching and popular music pedagogy]. In M-L Juntunen, H. M. Nikkanen, \& H. Westerlund (Eds.), Musiikkikasvattaja: Kohti refektiivistä käytäntöä (pp. 93-104). Jyväskylä, Finland: PS-Kustannus.

Väkevä, L., \& Westerlund, H. (2007). Te "method" of democracy in music education. Action, Criticism, and Theory for Music Education, 6(4), 96-108.

Vygotsky, Lev. (1978). Mind in society: The development of higher psychological processes. Cambridge, MA: Harvard University Press.

Waldron, J. (2009). Exploring a virtual music "community of practice": Informal music learning on the Internet. Journal of Music, Technology and Education, 2(2-3), 97-112.

Waldron, J. (Ed.). (2015). Participatory culture. [Special issue]. International Journal of Community Music, 8(1).

Waldron, J. L., \& Veblen, K. K. (2008). The medium is the message: Cyberspace, community, and music learning in the Irish traditional music virtual community. Journal of Music, Technology and Education 1(2-3), 99-111.

Wenger, E. (1998). Communities of practice. Learning, meaning, and identity. Cambridge, UK: Cambridge University Press. 
Wenger, E. (2006). Learning for a small planet - a research agenda. Retrieved from http://www. ewenger.com.

Wenger, E., White, N., \& Smith, J. D. (2009). Digital habitats: Stewarding technology for communities. Portland, OR: CPsquare.

Westerlund, H. (2008). Justifying music education: A view from here-and-now values experience. Philosophy of Music Education Review, 16(1), 79-95.

Wilson, C., Grizzle, A., Tuazon, R., Akyempong, K., \& Cheung, C. (2011). Media and information literacy curriculum for teachers. Paris: UNESCO. 